\title{
Exploring the Innovation and Entrepreneurship Education in College Education in China
}

\author{
Xing-Min SHI ${ }^{1, a,{ }^{*}}$ and Jun-Mei SUN ${ }^{1, b}$ \\ ${ }^{1}$ Hangzhou Normal University, Hangzhou, P.R. China \\ ashixingmin@hznu.edu.cn, bjunmeisun@hznu.edu.cn \\ ${ }^{*}$ Corresponding author
}

Keywords: Innovation Education, Higher Education, Challenge.

\begin{abstract}
Innovation and entrepreneurship education is becoming an important part of college education in China in the context of mass entrepreneurship and innovation. China's innovation and entrepreneurship education have made great progress in education system planning, curriculum development, platform construction, tutor training, and school-enterprise cooperation. However, the exploration of innovation and entrepreneurship education has just begun. The curriculum system of innovation and entrepreneurship education needs to be improved, the quality of the teaching staff still needs to be improved, and the schooling model still needs to be explored.
\end{abstract}

\section{Introduction}

In recent years, innovation and entrepreneurship education is becoming more attractive for all colleges and universities in China, and it has become a very important part of talent training in colleges and universities. According to the data in the Blue Book for the Development of Innovative and Entrepreneurial Education in Chinese Universities in 2017, the environmental friendliness of China's entrepreneurship has increased significantly, and China's public entrepreneurial will be ahead of the rest of the world.

The institutional and systematic framework of innovation and entrepreneurship education in Chinese universities has gradually been born out. Innovation and entrepreneurship courses are gradually being formed and improved. Students' awareness of innovation and entrepreneurship is also constantly improving. However, the status quo is still very serious, and there are still many problems that need to be resolved. At present, innovation and entrepreneurship education in most colleges and universities in our country still remains theoretical, and the practicality is yet to be tested. The methods, methods, and effects of innovation and entrepreneurship education still take time to test.

The paper is organized as follows: Firstly, it introduces the basic concepts of innovation and entrepreneurship education and the necessity of innovation and entrepreneurship education in colleges. Next, current major progress of innovation and entrepreneurship education in Chinese universities is described in detail. Furthermore, main issues and challenges topics of innovation and entrepreneurship education are discussed specifically. And a brief summary is given in the end.

\section{Innovation and Entrepreneurship Education}

Entrepreneurial education generally refers to the comprehensive quality related to entrepreneurship by cultivating various aspects of entrepreneurial awareness, entrepreneurial thinking, and entrepreneurial skills, and through this schooling, educators have a certain education system with entrepreneurial ability [1]. Compared with entrepreneurial education, the requirements for innovation and entrepreneurship education are higher [2]. Innovation and entrepreneurship education is proposed in the new social context at the present stage to cultivate innovative talents with innovative entrepreneurial consciousness. Its purpose is to cultivate the innovative talents with capabilities required by the national strategic planning and social development, and it provide a brand new education mode. 
The university is an important place for cultivating talents for the society and the country [3]. If we wish to carry out innovation and entrepreneurship education, it is bound to start from the university. Innovation and entrepreneurship education in colleges and universities need to have two purposes: First, the essence of innovation and entrepreneurship education in universities is to cultivate the college students' entrepreneurial awareness and practice capabilities, and train the university students into the innovative and comprehensive talents qualified for the requirements of social development and the country. Secondly, the scope of university innovation and entrepreneurship education provides the service for students which have entrepreneurial awareness and intent to start their own business.

\section{The Main Work for Innovation and Entrepreneurship Education}

Innovation and entrepreneurship are complex contents. They contain technical innovation, product innovation, brand innovation, and service innovation. Therefore, college students should strengthen their basic knowledge and set up their own business with innovative ideas and make a viable plan to make entrepreneurial activities successful [4]. In the specific innovation and entrepreneurship education in colleges and universities, teachers should regard the innovative spirit, entrepreneurial awareness, and entrepreneurial ability of college students as an important training goal, and ultimately create a comprehensive model with strong innovative thinking, practical operation ability, and high research level. Entrepreneurs of college students are required to integrate all the elements of society and production practice, and transform the achievements of scientific and technological innovation. This will result in a positive effect on economic progress and social innovation [5].

For most Chinese universities, the current work in innovation and entrepreneurship education mainly includes the following aspects:

1) Construction of Innovation and Entrepreneurship Education Courses. Innovation and entrepreneurship course basically falls into two categories: public basic course and professional course. Basic course focusses on enriching students' knowledge about innovation and entrepreneurship. Professional course is practical based on professional knowledge that can improve students' practical ability. Such courses include various innovations and entrepreneurship competitions, college students extracurricular work competitions, innovation and entrepreneurship forum and lectures, and innovation and entrepreneurship practices in industrial corporations.

2) Creating innovation and entrepreneurship education platform. In China, many universities have set up innovation and entrepreneurship colleges to provide platform support for innovation and entrepreneurship education, plan innovation and entrepreneurship course, and explore new models of professional education in fostering innovative talents. In addition, many colleges and universities are striving to build their own creative space, providing space for college students to innovate and entrepreneurship, formulate incentive policies, and provide related services.

3) Tutor training for innovation and entrepreneurship education. In order to enhance teachers' professional ability and level in innovation and entrepreneurship, the government and colleges and universities organize teachers to participate in entrepreneurial tutor training.

4) School-enterprise cooperation in the innovation and entrepreneurship education. The cooperation between institutions and enterprises has a lot of benefits. On the one hand, outstanding technology and business concepts can be utilized to promote the reform of schooling; on the other hand, entrepreneurial experience can be refined into valuable teaching materials. In addition, enterprise experts can also serve as special tutors for innovation and entrepreneurship education in schools, sharing their experience with students.

\section{Challenges of the Innovation and Entrepreneurship Education}

Although China's innovation and entrepreneurship work have been fully carried out and many achievements and achievements have been made in many aspects, innovation and entrepreneurship education still has many problems to be solved in the next few years. 
First, it is necessary to explore suitable modes of innovation and entrepreneurship education in various subject fields, especially in the course construction. The objective and the orientation of innovation and entrepreneurship education for undergraduates are not clear, and more efforts are devoted to the professional construction, discipline construction and employment. Innovation and entrepreneurship work is still based on traditional teaching models. There is too many theoretical guidance for entrepreneurship course, and practicality is poor. In addition, most of the innovation and entrepreneurship education courses in colleges and universities are based on elective course, entrepreneurship lecture and forum. They are short in time and inferior in practice. Students can only stay in the concept of understanding for innovation and entrepreneurship. The practice of innovation and entrepreneurship education in universities is more reflected in organizing students to participate in various types of competitive activities for innovation and entrepreneurship.

Moreover, a reasonable curriculum system for innovation and entrepreneurship education should be built and improved. From the point of view of the curriculum of innovation and entrepreneurship education, most course related to the innovation and entrepreneurship education in domestic universities is designed based on foreign curriculum. The curriculum generally includes enterprise establishment, investment and financing, marketing, corporate management, financial management, etc. In general, the curriculum setting of innovation and entrepreneurship education in Chinese universities is relatively fragmented, the number of courses is limited and the homogeneity is serious. The basic courses and practical courses are not enough, the practicality still needs to be improved, and the existing course cannot satisfy the needs of students with different professional backgrounds. As a result, a perfect innovation and entrepreneurship education system need to be formed and improved in order to provide students with a full range of innovation and entrepreneurship education to meet the practical needs of different students.

Furthermore, insufficient teachers are still a key limiting factor to the further development of innovation and entrepreneurship education. From the start of innovation and entrepreneurship education in Chinese universities to the present, teachers in innovation and entrepreneurship education have been considerably improved through the means of teacher training and entrepreneurship training. However, subjected to the scope and scale of innovation and entrepreneurship education, it is still clearly inadequate. In addition, the overall quality of the faculty involved into the existing innovation and entrepreneurship education is generally low. They are not able to learn the systematic knowledge of innovation and entrepreneurship, have little practical experience in innovation and entrepreneurship, and even do not fully understand the target professional field for some of them. Poor capability has greatly weakened the result of the guidance in innovation and entrepreneurship education.

\section{Summary}

In short, the university's innovation and entrepreneurship education is of great importance to the development of our society and the improvement of China's overall national strength. Training innovative and entrepreneurial talent through innovation and entrepreneurship education, not only satisfies the need of the society for innovation and entrepreneurial talents, but also can effectively alleviate university students. Employment pressure provides the impetus for social development. After years of exploration, China's atmosphere of innovation and entrepreneurship has become increasingly strong. Innovative and entrepreneurial enterprises have increased. However, the exploration of innovation and entrepreneurship education has just begun. The curriculum system of innovation and entrepreneurship education urgently improved, the quality of the teaching staff still needs to be strengthened, and the educational model still needs to be explored.

\section{Acknowledgement}

This research was supported by the Ministry of Education's 2016 School-Enterprise Cooperative Education Project (No. 201602014065), “Innovation and Entrepreneurship Project Incubator 
Platform”, and thanks Yalong Intelligent Equipment Group Co., LTD. for its funding support for this innovative entrepreneurial talent training program.

\section{References}

[1] Donald F. Kuratko, The emergence of entrepreneurship education: development, trends, and challenges, Entrepreneurship Theory and Practice, 29(2005) 577-598.

[2] Peter Drucker, Innovation and Entrepreneurship, Routledge Classics, 2015.

[3] Douglas H. G., Andreia D. L., Regiane R. R., Program Entrepreneurship and Innovation: Education as the Core of Innovation, Advances in the Human Side of Service Engineering, 2017, pp. 235-244.

[4] Jonathan M. Scott, Andy Penaluna, John L. Thompson, A critical perspective on learning outcomes and the effectiveness of experiential approaches in entrepreneurship education: Do we innovate or implement?, Education + Training, 58(1), 2016

[5] Weilerstein P., Byers T., Guest Editorial: Entrepreneurship and Innovation in Engineering Education, Advances in Engineering Education, 5(1), 2016. 